\title{
THE DETERMINANTS OF NON-COGNITIVE EDUCATION: DOES SCHOOL MATTER? EMPIRICAL EVIDENCE FROM SPAIN
}

\author{
García-Valiñas, Marián \\ (mariangv@uniovi.es) \\ Muñiz-Pérez, Manuel \\ (manumuni@uniovi.es) \\ Suárez-Pandiello, Javier \\ (jspandi@uniovi.es)
}

Department of Economics, University of Oviedo (Spain)

\section{Introduction.}

The interest for the measurement and evaluation of Secondary Education outputs is a highly topical subject, in order to identify efficiency and equity problems in national educational systems. In this respect, PISA initiative (Programme for International Student Assessment) has got especial significance and scope during the last decade. This is an international test whose results allow us to make a diagnostic of the main problems in our own educational system, but also to compare our situation with other countries which are participating in the program. However, all the studies in the literature are focused on cognitive results in some specific subject at the curriculum (Maths, Science, Language...), neglecting the non-cognitive dimension of educational output ${ }^{1}$. The main reasons for this exclusion are the lack of objective proofs to evaluate this dimension and also the difficulties to set a standard definition of citizenship or other social values (Cohn and Geske, 1990).

Moreover since the first steps of Education Economics ${ }^{2}$, the multidimensional character of educational output has been shown. Specifically, the literature has distinguished two components of educational results: cognitive outputs (intellectual abilities and specific knowledge) and non-cognitive outputs (affective values, social behaviour and personal maturity). There is also a generalized agreement that both dimensions might be considered in the evaluation of educational systems. That means that the schools are not only knowledge transmitters, but they have to try to instil some guidelines to develop collective and personal abilities. This kind of features leads to improve labour and social integration, communication and interaction abilities, the deference towards the environment or the political, social and personal responsibility ${ }^{3}$. In a similar way, the literature on education issues has suggested that in those schools where affective education has been developed, positive effects have been observed, in both cognitive and non-cognitive dimensions (Watkins et al, 1991; Nixon et al, 1996).

The main aim and contribution of this paper is double. First of all, we would like to identify and analyze the scope of the determinants (at individual and school level) of non-cognitive dimension of educational output. Secondly, we would like to test its connexion with the parents' choice of the school for their children. To illustrate both objectives, we will carry out an empirical application in the Spanish case.

The discussion about private versus public management, and the subsequent choice between both alternatives, is a controversial topic in the literature on Education Economics, since Coleman studies $(1966,1982)$. Additionally, this research topic is especially interesting in the Spanish case. By one side, in our educational system the

\footnotetext{
${ }^{1}$ See Hanushek $(1986,1997,2003)$ or Worthington (2001).

${ }^{2}$ For instance, see Bloom et al., 1956.

${ }^{3}$ Among others, see Pring (1984), Lang et al. (1998) or Best (2003).
} 
service is provided by means of several organizational frameworks. By the other side, there could be differences in the orientation of non-cognitive education depending on the kind of management, which are taken into account by the parents to choose of the school that they prefer for their children. This study also contributes by means of the elaboration and use of an original survey to more than 5.000 students of Secondary School in Spain. This survey allows getting information about civic and social education of Spanish students.

\section{School choice in Spain.}

Depending on both the ownership and the financial support source, in Spain it is possible to distinguish three kind of educational centres: First, public schools, with public ownership and funding (approximately $2 / 3$ of the total supply). Second, grantaided schools, where the ownership is private but they receive public funds. Those schools must satisfy the public state requirements, which are imposed to all the schools in the public network (they involve around $1 / 4$ of the total supply). Finally, there are private schools, with private ownership and funding (7\% of the total supply). This study has been exclusively focused on the two first categories, due to the difficulties to get private schools' information.

So, although the minor weight that the grant-aided schools have on the Spanish education network, parents have a strong preference towards them. The main differentiating features of those centres from public schools are their mostly catholic orientation, a higher socioeconomic status of their students, and a lower presence of immigrants or socially disadvantaged students (despite the admission rules are the same that those applied in public centres). The most evident answer for this high demand in grant-aided schools could be the better academic results provided by them. In fact, all the studies that have analyzed the Spanish case comparing public and grant-aided schools (Calero and Escardibul, 2007; Mancebon and Muñiz, 2007; Mancebon and Perez-Ximenez de Embun, 2007; Calero and Wasgrais, 2009; Perelman and Santin, 2011; Salinas and Santin, 2012) lead to the same conclusion: better academic results of grant-aided schools in global terms, but similar results once they controlled by the socioeconomic status of the students (even in some cases, slightly better results in the case of public schools).

Therefore, in order to explain the preference for grant-aided schools, previous literature has neglected the explanation based on an upper educational training offered at that kind of schools. In this working paper we analyze an alternative argument: some parents consider that the non-cognitive education which is provided by public schools is different and worse than the one which is provided by grant-aided and private schools. So parents can value in a higher way some school characteristics that from their point of view could lead to a better non-cognitive education, such as higher discipline and control on students' behaviour or a more hierarchical relationship among teachers and students.

In a first step of our empirical analysis, we will try to test such a hypothesis: that is, if there are real differences in non-cognitive education depending on the kind of school or by the contrary, if the choice is based on prejudices. Next, we will identify the most important determinants of non-cognitive output.

\section{Data and empirical analysis aims}

As we mentioned previously, there is a lack of empirical data related to noncognitive outputs. This fact contrast with the wealth of information linked to the 
cognitive dimension of educational output. So it was necessary to design and conduct a survey, in order to obtain the missing information.

Once we checked the literature linked to non-cognitive education and its determinants, some concepts were selected and included as non-cognitive output into the analysis. Two categories were set, including five features in each one. The first category includes some "universal values" such as Justice, Equality, Democracy, Responsibility and Tolerance. The second one is linked with some "social, emotional and intellectual competences", including Motivation, Empathy, Self-control, Effort and Criticism ability. Moreover, some potential determinants of non-cognitive dimension were identified. Among others, it is possible to mention a set of factors linked to the school (ownership, location, peer-group effect), to the student (gender, cognitive results) or to his family environment (socioeconomic status, parents' age and education level, family structure and size, immigration, etc). Once we selected the main variables in which the survey might focus on, we designed the questionnaire, including 53 multiplechoice questions with 4 possible answers each. From all of them, 20 are related to outputs. By means of contextual questions and using 2 questions for each dimension/item, we try to approximate a measure of non-cognitive educational output. The other 33 questions are related to the determinants of this educational dimension.

The survey includes information about the students in the last course of compulsory secondary school (teenagers around 15 years old) during the academic course 2010-2011 at grant-aided and public schools in Asturias (Spain). The whole population were around 7,072 students in 136 schools, of which 80 were public $(4,676$ students) and 56 were grant-aided (2,396 students). The final sample includes 5,580 students, which means the $78.90 \%$ of the total population survey. Answering percentages were similar in both kinds of schools. Once we registered the questionnaires, we obtained a final data base with 5.493 observations, 3.497 related to public schools and 1.996 to grant-aided schools. Following several experts' recommendations, we design the four possible answers in each situation including one answer to identify the best option for each dimension. In a parallel way, we also included an answer to show the worse attitude from a social point of view. This design allows getting a symmetric structure in the empirical analysis, considering both good and bad results in non-cognitive outputs.

In particular, we design two additive output indexes. The first one or positive index is built giving the value 1 to the students that answer simultaneously the best option (that means, the one that show the most adequate behavior) in the two questions for each item/dimension. Additionally, we design the negative index assigning the value 1 when the students answer the "reprehensive" option in one or the two questions for each item/dimension. Thus, we have two different indexes with the same rank, from 0 to 10. The tests to check the consistence of the two global indexes were satisfactory. The Cronbach's alpha takes the value $0,66^{4}$ and all the correlations item/total take values higher than 0,45 for the ten items considered. As a previous step to the analysis of the school ownership effect, we show some data in Tables 1 and 2. Thus, it is possible to observe the percentage of students with value 1 for each dimension/item, depending on the school ownership. It is also shown the average value for each kind of school.

First of all, we emphasize that both kind of schools take almost the same average value for the positive index (there is only a 0.04 points difference). This figure lead to think that school ownership does not lead to a big gap in the social and affective

\footnotetext{
${ }^{4}$ The literature suggests Cronbach's alpha values higher than 0.6-0.7, depending on the item's heterogeneity. In our case, the global index has a significant heterogeneity, so a value of 0.66 can be interpreted as an adequate and consistent result.
} 
education. If we look at particular dimensions/items, neither significant difference is found. In the case of the negative index, the results are also similar (there is a 0.06 point difference in the average value).

DIMENSION/ITEM
Justice
Equality
Democracy
Responsibility
Tolerance
Motivation
Empathy
Self-control
Effort
Criticism

AVERAGE INDEX

\begin{tabular}{|c|c|}
\hline PUBLIC & GRANT-AIDED \\
\hline 19.4 & 23.2 \\
40.1 & 39.9 \\
\hline 29.9 & 28.0 \\
15.2 & 15.4 \\
29.7 & 29.3 \\
15.4 & 13.8 \\
\hline 30.5 & 31.6 \\
14.0 & 13.4 \\
\hline 32.6 & 31.3 \\
\hline 50.2 & 54.8 \\
\hline $\mathbf{2 . 7 6}$ & $\mathbf{2 . 8 0}$ \\
\hline
\end{tabular}

Table 1. Positive index: dimension/item and average frequencies, by school ownership.

Definitively, as a first approach and considering the figures related to both positive and negative indexes, it would be possible to conclude that school ownership seems irrelevant in order to explain the results of non-cognitive education. Regarding the findings by dimension/item, grant-aided schools show better results in Justice, Empathy and Criticism. Public schools obtain better marks in Equality, Democracy and Tolerance. Even so, those partial differences by item are not significant enough to choose a particular ownership option as the best one.

DIMENSION/ITEM
Justice
Equality
Democracy
Responsibility
Tolerance
Motivation
Empathy
Self-control
Effort
Criticism

\section{AVERAGE INDEX}

\begin{tabular}{|c|c|}
\hline PUBLIC & GRANT-AIDED \\
\hline 36.3 & 40.0 \\
\hline 88.8 & 87.4 \\
\hline 78.8 & 78.3 \\
\hline 38.7 & 36.0 \\
83.1 & 80.8 \\
73.0 & 73.3 \\
74.3 & 78.4 \\
80.4 & 83.6 \\
76.5 & 77.3 \\
73.2 & 74.7 \\
$\mathbf{7 . 0 3}$ & $\mathbf{7 . 0 9}$ \\
\hline
\end{tabular}

Table 2. Negative index: dimension/item and average frequencies, by school ownership

In the next section we test those intuitions in a formal way. First of all, we will use a basic ANOVA analysis, and after we will use an ordered probit methodology. In the last one, we will include, by one side, other two factors which can have influence on the results and are also related to the school (location and peer group effect) and by the other side, a set of individual and familiar variables. 


\section{Results.}

By means of ANOVA methodology, we test if the students' average results related non-cognitive education are influenced by school ownership. The main idea with this method is not to find differences among the same mean value for different kind of schools. The key issue will be to identify statistically significant differences among schools, using the Fisher-Snedecor F distribution.

ANOVA analysis' results for both positive and negative indexes are shown in Table 3. The obtained values confirm the hypothesis that school ownership is not significant to explain this kind of education. No big differences among means were found. Additionally, after repeating the same test by items, we do not observe significant values in general. In the case of the positive analysis (positive index), there are some significant differences in the items related to Justice and Criticism, in both cases with higher values for grant-aided schools. Looking at the negative analysis' results, there are more significant differences by items than in the positive analysis. However, from a global point of view, no significant differences are found. In favor of public schools, we find some items like Responsibility or Tolerance. Students from grant-aided schools are better in other values, like Justice, Empathy and Self-control.

\begin{tabular}{lcccc} 
& \multicolumn{4}{c}{ POSITIVE ANALYSISNEGATIVE ANALYSIS } \\
Justice & $\mathrm{F}$ & Sig. & $\mathrm{F}$ & Sig. \\
Equality & 11.217 & $\mathbf{0 . 0 0 1}$ & 7.470 & $\mathbf{0 . 0 0 6}$ \\
Democracy & 0.019 & 0.890 & 2.195 & 0.139 \\
Responsibility & 2.216 & 0.137 & 0.256 & 0.613 \\
Tolerance & 0.050 & 0.824 & 4.168 & $\mathbf{0 . 0 4 1}$ \\
Motivation & 0.085 & 0.770 & 4.642 & $\mathbf{0 . 0 3 1}$ \\
Empathy & 2.618 & 0.106 & 0.066 & 0.797 \\
Self-control & 0.732 & 0.392 & 11.744 & $\mathbf{0 . 0 0 1}$ \\
Effort & 0.402 & 0.526 & 8.276 & $\mathbf{0 . 0 0 4}$ \\
Criticism & 1.042 & 0.308 & 0.468 & 0.494 \\
GLOBAL INDEX & 10.899 & $\mathbf{0 . 0 0 1}$ & 1.565 & 0.211 \\
(2) & 0.389 & $\mathbf{0 . 5 3 3}$ & 1.535 & $\mathbf{0 . 2 1 5}$
\end{tabular}

Table 3. ANOVA results: positive and negative indexes by dimension/item

The next step in the empirical exercise consists of a regression analysis, in order to identify the main determinants of non-cognitive education. The use of an ordered probit is generally recommended when the dependent variable is discrete and ranked. This is our situation, where both positive and negative global indexes take values ranked from 0 to 10 . So we specify 4 different models. In the Models 1 and 2, both positive and negative index are respectively used as dependent variables. Those models also consider as independent variables those related to the school: ownership (public/grant-aided), location (urban/rural) and peer-group effect. The first two variables are dummy variables. Peer-group variable is built calculating the average value for the global results (of the positive index in the Model 1, and of the negative index in the Model 2) in the class, excluding the results of the student interviewed. The main objective of this variable is to test the influence of a "good" or "bad" environment (his/her classmates' non-cognitive and social education) on the student's results.

In models 3 and 4, the same dependent variable framework remains. We also add other independent variables related to individual and family socioeconomic features. Table 4 describes all the explanatory variables used in the models. 


\begin{tabular}{|c|c|}
\hline VARIABLE & DEFINITION \\
\hline pgpos & $\begin{array}{l}\text { Positive index average value for the class, excluding the results of the student } \\
\text { himself }\end{array}$ \\
\hline pgneg & $\begin{array}{l}\text { Negative index average value for the class, excluding the results of the student } \\
\text { himself }\end{array}$ \\
\hline pc & School ownership $(0=$ public, $1=$ grant-aided $)$ \\
\hline ur & School location $(0=$ urban, $1=$ rural $)$ \\
\hline genero & Male $=0$, Female $=1$ \\
\hline edad16 & Age 16 years old $=1$, otherwise $=0$ \\
\hline edad17 & Age 17 years old $=1$, otherwise $=0$ \\
\hline inmignac & Student born in another country $=1$, born in Spain $=0$ \\
\hline inmig1 & Student born in Spain, one parent born in another country $=1$, otherwise $=0$ \\
\hline inmig2 & Student born in Spain, both parents born in another country $=1$, otherwise $=0$ \\
\hline rep & Student has retaked or is retaking a course $=1$, otherwise $=0$ \\
\hline progdc & Student taking the Diversification Curriculum Program $=1$, otherwise $=0$ \\
\hline expnot & Average grade of B in the last course $=1$, otherwise $=0$ \\
\hline expsb & Average grade of $\mathrm{A}$ in the last course $=1$, otherwise $=0$ \\
\hline estpaegb & Father with primary education $=1$, otherwise $=0$ \\
\hline estpabac & Father with secondary education $=1$, otherwise $=0$ \\
\hline estpauni & Father with higher education $=1$, otherwise $=0$ \\
\hline estmaegb & Mother with primary education $=1$, otherwise $=0$ \\
\hline estmabac & Mother with secondary education $=1$, otherwise $=0$ \\
\hline estmauni & Mother with higher education $=1$, otherwise $=0$ \\
\hline profpa & Father with a qualified job $=1$, otherwise $=0$ \\
\hline profma & Mother with a qualified job $=1$, otherwise $=0$ \\
\hline edadpa1 & Father's age between 36 and $45=1$, otherwise $=0$ \\
\hline edadpa2 & Father's age higher than $45=1$, otherwise $=0$ \\
\hline edadmal & Mother's age between 36 and $45=1$, otherwise $=0$ \\
\hline edadma2 & Mother's age higher than $45=1$, otherwise $=0$ \\
\hline hermanos1 & Student with one brother/sister $=1$, otherwise $=0$ \\
\hline hermanos 2 & Student with $2-3$ brothers/sisters $=1$, otherwise $=0$ \\
\hline hermanos3 & Student with more than 3 brothers/sisters $=1$, otherwise $=0$ \\
\hline familiauni & Student living with only one parent $=1$, otherwise $=0$ \\
\hline familianue & Student living with only one parent and his/her couple $=1$, otherwise $=0$ \\
\hline ingresos1 & Monthly family income between 1.000 and 1.500 euros $=1$, otherwise $=0$ \\
\hline ingresos 2 & Monthly family income between 1.500 and 2.000 euros $=1$, otherwise $=0$ \\
\hline ingresos3 & Monthly family income higher than $2.000=1$, otherwise $=0$ \\
\hline
\end{tabular}

\section{Table 4. Definition of explanatory variables included in the ordered probit}

The results of the four models are shown in the Appendix 1. In Models 1 and 2, which consider only school factors as explanatory variables, it is shown that ownership is irrelevant in order to explain the global results about social competences or noncognitive education. In the same way, school location is not significant at all. No differences between urban and rural schools are found. By the contrary, peer-group effect is significant at $99.9 \%$ in both models. That finding means that the school where the student is taking the courses matter. However, ownership and location are not key factors. The main issue is his/her class environment. Thus, a student has a higher probability to have a good social and civic education if his/her classmates have good results in non-cognitive education, and the opposite is also true. So this idea refutes the neutrality of the school in the student's non-cognitive education. The fact that there were schools with better or worse students (from the point of view of social education) and not the ownership, gives importance to the school's choice.

Regarding the individual variables which are significant at $99.9 \%$, girls have better results than boys. Additionally, being a first generation immigrant (to be born in a 
foreign country) has a positive impact on non-cognitive outcome. The sign is just the opposite if we consider the next generation (born in Spain with foreign parents), but it is not significant. There is also a strong correlation between social competences and student's academic records. That fact shows the relationship between both dimensions of educational output, remarked by the literature.

If we look at the parents' characteristics, we observe a positive impact when the father has achieved secondary education level. This effect is also observed for the mother, but in this case, the level of education shown a more consistent effect. Those findings change when we talk about the age. In this case the effect in the case of the father is significant for all the age scales. Anyway, it is positive for both parents. No professional qualifications neither the income level are significant factors. With regard to the family composition, being only child or having brothers/sisters does not matter. However, one-parent families have a negative and significant impact on this kind of education. It might be emphasize there is a complete symmetry between the positive and negative analysis, except in the case of mother's education level. For the remaining variables, the results are close one each other.

Finally, as the coefficients of the probit regression have not a direct interpretation (and in consequence, the scope of the effects), we estimate marginal effects for each variable. We include the results into the Appendix 2. To simplify and make easier the interpretation, we show only the marginal effects of significant variables in the Models 3 and 4, for the extreme values 0, 1, 9 and 10. Thus for instance, the probability of obtaining a 0 value for the positive index decreases in a $7.03 \%$ in the case of being a female student. In a similar way, to have A marks on average increase the probability to get the value 10 for the positive index around $0.25 \%$. The values obtained for marginal effects register a similar significance than the coefficients estimated in the ordered probit. So the peer-group effect, the gender, the student's academic records and the father's age emerge as the main determinants of non-cognitive education.

\section{Conclusions.}

The evaluation of Secondary Education output is a highly topical subject. However, all the empirical literature has focused on measuring the cognitive dimension of the educational system, neglecting non-cognitive outputs (related to affective values and social behavior). The lack of standard exams to measure that kind of outputs is the main reason for this omission. Nevertheless, affective education is unanimously considered as a very important issue in the process of young people's education.

In this paper we analyze the links between non-cognitive outputs and the school characteristics. This topic is a key issue in the Spanish case, where there is a public education network where public and grant-aided schools rival to get the students. Thus, it seems that parents' school choice is biased towards the last category of schools, reducing the demand of public schools. The literature has shown that bias is not explained by the results of the cognitive dimension. It only remains to find out if parent's perceptions about the non-cognitive education matters in this choice.

Our findings (obtained by means of descriptive statistics, ANOVA and ordered probit analysis) show that school ownership is not a significant factor to influence noncognitive education. Those results lead to reject the idea that the high demand for grantaided schools was explain by a higher social an affective education provided by this kind of schools. However, we have observed that there are some school characteristics which matter, like the peer-group effect. So it does not mind that the school was public or grant-aided, but the student composition at the school is a very important factor. 
Regarding individual and family features, we found that gender, academic records and father's age have a strong impact on students' non-cognitive education. However, there are other factors which have not shown a significant effect on this kind of education, like income, parent's job (those variables used to be significant in the case of cognitive competences) or family size.

This research's findings lead to reinforce the role of schools as providers of noncognitive education. The important impact of individual and familiar variables compared with the effect of school features (in the same direction the literature on cognitive outputs shows) could be an outstanding signal. It is possible that schools are not doing all the possible efforts to avoid that the social and familiar environment determines the student's education (non-cognitive in this case) exclusively. And the school's role is a key issue to design public policies guided towards getting equality of opportunities in the educational system.

\section{References}

Best, R. (2003). "New bottles for Old Wine? Affective Education and the Citizenship Revolution in English Schools", Pastoral Care in Education, 21(4): 14-21.

Bloom, B.S., Engelhart, M.D., Furst, E.J., Hill, W.H. and Krathwohl, D.R. (1956). Taxonomy of educational objectives. New York, David McKay Company.

Calero, J. and Escardibul, J.O. (2007). "Evaluación de servicios educativos: el rendimiento de los centros públicos y privados medido en PISA-2003", Hacienda Publica Española, 183(4): 33-66.

Calero, J. and Waisgrais, S. (2009). "Factores de desigualdad en la educación española. Una aproximación a través de las evaluaciones PISA", Papeles de Economía Española, 119: 86-99.

Cohn and Geske (1990) The Economics of Education, Pergamon Press.

Coleman, J., Campbell, E.Q., Hobson, C.F., McPartland, J. and Mood, A.M. (1966). Equality of Educational Opportunity. Washington, U.S. Office of Education.

Coleman, J., Hoffer, T. and Kilgore, S. (1982). "Cognitive outcomes in public and private schools", Sociology of Education, 55(2): 65-76.

Hanushek, E. (1986). "The Economics of Schooling: Production and Efficiency in Public Schools", Journal of Economic Literature, 24: 1141-1177.

Hanushek, E. (1997). "Assessing the effects of school resources on student performance: An update", Educational Evaluation and Policy Analysis, 19: 141-164.

Hanushek, E. (2003). "The failure of input based schooling policies", The Economic Journal, 113: 64-98.

Lang, P.L.F, Katz, Y. and Menezes, I. (Eds.) (1998). Affective Education. A Comparative View, Londres, Continuum.

Mancebón, M.J. and Perez-Ximenez de Embun, D. (2007)" Conciertos educativos y seleccion academica y social del alumnado", Hacienda Publica Española, 180: 77-106.

Mancebón, M.J. and Muñiz, M.A. (2007).” Private versus Public High Schools in Spain: disentangling managerial and program efficiencies", Journal of the Operational Research Society, 59-7: 892901.

Morgan, S. and Sorensen, A. (1999). "Parental networks, social closure and mathematics learning", American Sociological Review, 64: 661-681.

Nixon, J., Martín, J., McKeown, P. and Ranson, S. (1996). Encouraging Learning: Towards a theory of the learning school. Milton Keynes, Open University Press.

Perelman, S. and Santin, D. (2011). "Measuring educational efficiency at student level with parametric stochastic distance functions: an application to Spanish PISA results", Education Economics, 19(1): 29-49.

Pring, R. (1984). Personal and Social Education in the Curriculum. Londres, Hodder y Stoughton.

Salinas, J. and Santin, D. (2012). "Selección escolar y efectos de la inmigración sobre los resultados academicos españoles en PISA 2006", Revista de Educación, 358, in press.

Sullivan, A. (2001). "Cultural capital and educational attainment", Sociology, 35: 835-912.

Watkins, C., Lodge, C. and McLaughlin, C. (Eds.) (1991). Gender and Pastoral Care. Oxford, Blackwell.

Worthington, A. (2001). "An empirical survey of frontier efficiency measurement techniques in education", Education Economics, 9 (3): 245-268. 


\section{\begin{tabular}{|l|l|l|l|} 
MODELO 1 & MODELO 2 & MODELO 3 & MODELO 4
\end{tabular}}

Appendix 1. Ordered probit analysis results .

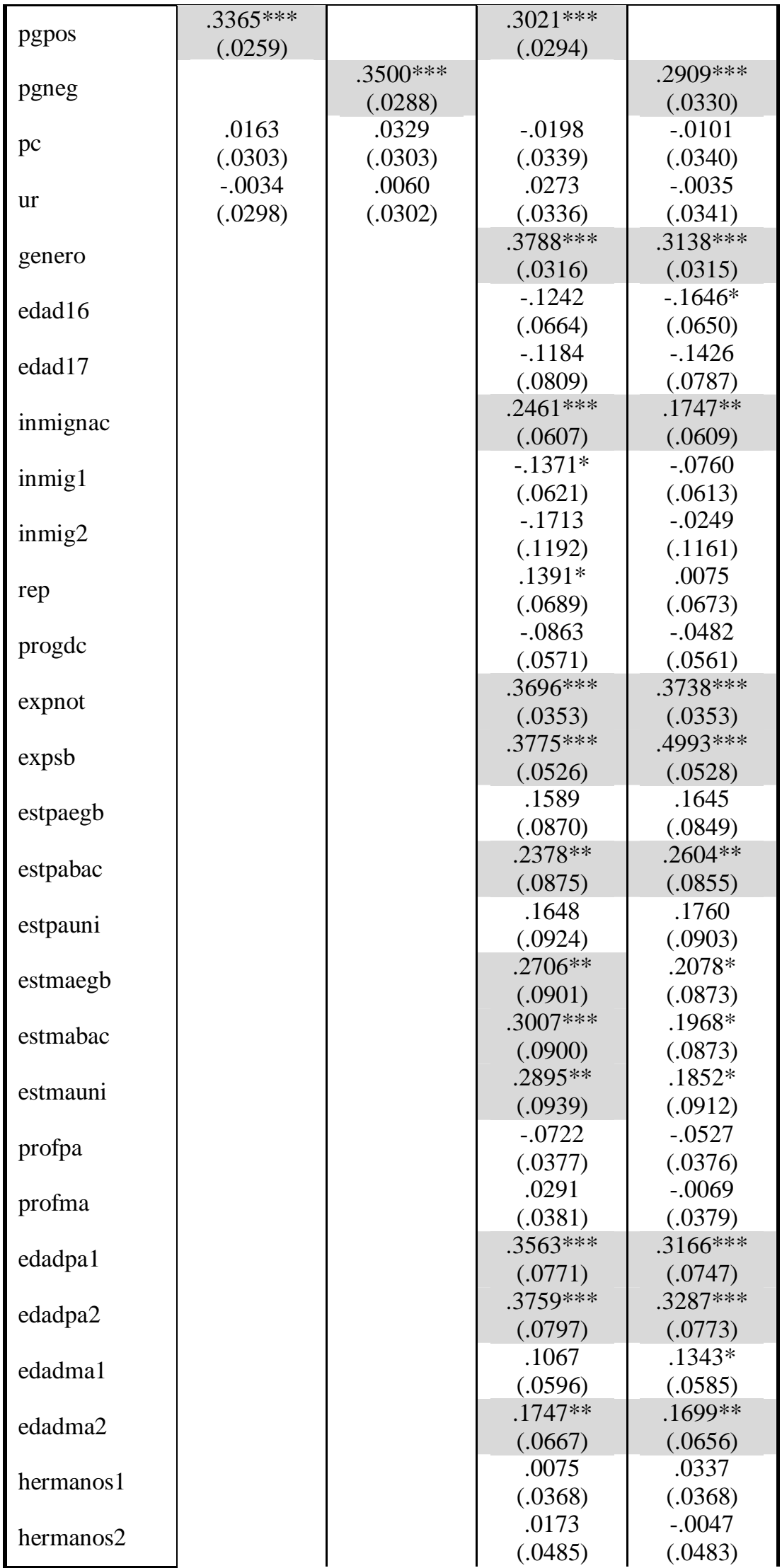




\begin{tabular}{|c|c|c|c|c|}
\hline hermanos3 & & & $\begin{array}{c}.0049 \\
(.0870)\end{array}$ & $\begin{array}{c}-.0044 \\
(.0861)\end{array}$ \\
\hline & & & $-.1069 * *$ & $-.0996 * *$ \\
\hline tamıliaunı & & & $(.0373)$ & $(.0371)$ \\
\hline familianue & & & -.1287 & -.1037 \\
\hline & & & $(.0696)$ & $(.0686)$ \\
\hline inoresos1 & & & $.1207 *$ & .0869 \\
\hline ingesuse & & & $(.0588)$ & $(.0585)$ \\
\hline ingresos 2 & & & -.0011 & .0113 \\
\hline & & & $(.0590)$ & $(.0587)$ \\
\hline ingresos 3 & & & -.0744 & -.0454 \\
\hline & & & $(.0588)$ & $(.0583)$ \\
\hline $\mathrm{N}$ & 5493 & 5493 & 5493 & 5493 \\
\hline Log likelihood & -11274.021 & -10953.854 & -8955.2602 & -8474.3724 \\
\hline LRchi2 & 172.44 & 155.83 & 629.73 & 588.55 \\
\hline Prob>chi2 & .0000 & .0000 & .0000 & .0000 \\
\hline Pseudo R2 & .0076 & .0071 & .0340 & .0336 \\
\hline
\end{tabular}

$* * *$ Significant at $99.9 \%, * *$ significant at $99 \%$, *signifcant at 95 , standard errors in brackets

\section{Appendix2. Marginal effects at Models 3 and 4.}

\begin{tabular}{|c|c|c|c|c|c|}
\hline MODEL 3 & 0 & 1 & & 9 & 10 \\
\hline pg & $-5,63$ & $-4,72$ & & 0,42 & 0,12 \\
genero & $-7,03$ & $-5,85$ & & 0,55 & 0,17 \\
inmignac & $-4,03$ & $-3,89$ & & 0,44 & 0,14 \\
expnot & $-6,59$ & $-5,76$ & & 0,58 & 0,18 \\
expsb & $-5,87$ & $-5,93$ & & 0,74 & 0,25 \\
estpabac & $-4,24$ & $-3,73$ & & 0,36 & 0,11 \\
estmabac & $-5,31$ & $-4,71$ & & 0,47 & 0,15 \\
edadpa1 & $-6,45$ & $-5,54$ & & 0,54 & 0,17 \\
edadpa2 & $-7,08$ & $-5,79$ & & 0,53 & 0,16 \\
edadma2 & $-3,15$ & $-2,74$ & & 0,26 & 0,08 \\
familiauni & 2,06 & 1,65 & & $-0,14$ & $-0,04$ \\
AV.PROB. & 10,88 & 18,24 & & 0,52 & 0,12 \\
\hline
\end{tabular}

\begin{tabular}{|c|c|c|c|c|c|}
\hline MODEL 4 & 0 & 1 & & 9 & 10 \\
\hline pg & $-0,03$ & $-0,19$ & & 5,40 & 4,02 \\
genero & $-0,04$ & $-0,21$ & & 5,78 & 4,39 \\
inmignac & $-0,01$ & $-0,09$ & & 3,22 & 2,68 \\
expnot & $-0,04$ & $-0,23$ & & 6,86 & 5,50 \\
expsb & $-0,03$ & $-0,21$ & & 8,81 & 9,01 \\
estpabac & $-0,03$ & $-0,16$ & & 4,80 & 3,82 \\
estmabac & $-0,02$ & $-0,12$ & & 3,64 & 2,85 \\
edadpa1 & $-0,04$ & $-0,20$ & & 5,83 & 4,55 \\
edadpa2 & $-0,04$ & $-0,23$ & & 6,05 & 4,54 \\
edadma2 & $-0,02$ & $-0,10$ & & 3,14 & 2,45 \\
familiauni & 0,01 & 0,07 & & $-1,84$ & $-1,32$ \\
AV.PROB. & 0,03 & 0,22 & & 18,67 & 7,28 \\
\hline
\end{tabular}

